\title{
I DIDN'T KNOW ....
}

"I didn't know that Saskatchewan had a flora." She was a pretty girl and, as I discovered later in the class, intelligent. Yet she expressed a view that is unfortunately shared by all too many residents of Saskatchewan. The particular course I was involved with this summer had in addition to lectures, fourteen four-hour laboratory periods, six of which were spent in the field. In both laboratory and field students frequently voiced their amazement. As I heard their expressions of surprise when they saw a new sight, I often thought how much people miss when they do not take the trouble to look with an eye that really sees.

During each of our field trips we tried to visit more than one kind of habitat in uncultivated areas. This was not difficult because around wet spots there is usually a shrubby or treed area and above this, grasslands.

Native grasses have real beauty and interest and vary according to position on north-and-south-facing slopes, soil type and moisture availability. Native grasslands are rich in forbs such as scarlet mallow, chamaerhodos, cinquefoil, psoralea, astragalus and many others. On the prairie, above the claybanks of Avonlea Creek where the gumbo evening-primrose was in full bloom, we squatted on the short grass to key out the dainty pennyroyal, the mousetail and the delicate soft grey Pursh's plantain. On fairly open sand dunes west of Caron we examined a Cyperus and spent some time identifying the western virgin's-bower, the rare hairy prairie-clover and the bur-ragweed. In one low meadow the western red lily flamed among smooth camas, fringed loosestrife and windflower.

In the woods we saw a rich harvest of beaked hazelnuts and sampled fruits of goose-berries and various raspberries and currants. On some slopes we were careful to identify the poison ivy and distinguish it from wild sarsaparilla, baneberry and large divided leaves of several other plants with which it might easily be confused by an amateur botanist. In some such spots we identified the fragile fern and on two occasions the grape fern. On the same day we found in abundance red osier dogwood, high bush cranberry, saskatoonberry, chokecherry and pincherry.

When we went into moister areas, I gathered from the reaction of the students that mosit people tend to shun our bogs and willow thickets. This is indeed a pity for not only are the willows an extremely variable and interesting group but associated with them are rare and beautiful flowers. Here as elsewhere we stepped carefully to avoid crushing any rare specimen and we avoided picking in order not to affect or reduce the genetic diversity. In these damp spots we saw grass of parnassus, mealy primrose, shooting star, various orchids and wintergreen and the graceful twin flower called Limnaea for the first taxonomic botanist, Carl Linnaeus.

We examined at one point the butterwort whose greasy leaf glands have the ability to digest and utilize the food in pollen grains and in small insects. In a small pond we fished out some bladderwort to examine the little traps which the plant uses to catch and digest mosquito larvae and other small aquatic animals.

On the prairie slopes of the Missouri Coteau we looked at broom-rape - a parasite on the sage which was abundant as the result of overgrazing. In a wet springy bank where giant reed grass was already eight feet tall and the sunflowers and mints were luxuriantly rank and vegetative, we saw the long sickly orange strands of the dodder spreading from plant to plant and spiralling up the lengths of their hosts. The dodder, another of those parasites completely unable to make any of their own food, flowers abundantly; it illustrates the fact that the more hazardous the survival the more productive must be the seed set. A fascinating plant . . . "I didn't know Saskatchewan had a flora." 